\title{
PERILAKU MASYARAKAT DALAM PENGELOLAAN SAMPAH DAN FAKTOR-FAKTOR YANG MEMPENGARUHI DI KECAMATAN DENPASAR TIMUR KOTA DENPASAR, PROVINSI BALI
}

\author{
Ni Luh Gede Sukerti ${ }^{1 *}$, I Made Sudarma ${ }^{2)}$, I.B.G Pujaastawa ${ }^{3)^{\star}}$ \\ 1)Puskesmas I Denpasar Timur Kota Denpasar, \\ ${ }^{2}$ Dosen Fakultas Pertanian Universitas Udayana, \\ ${ }^{3}$ Dosen Prodi Antropologi Fakultas Ilmu Budaya Universitas Udayana \\ *Email : odhesarah@gmail.com
}

\section{ABSTRACT
COMMUNITY BEHAVIOR IN WASTE MANAGEMENT AND INFLUENCED FACTORS AT EAST DENPASAR DISTRICT, DENPASAR TOWN, BALI PROVINCE

Waste problem is one of the environmental issues that have long been the world's attention and need to get serious handling so as not to cause harmful impacts. Community behavior is the most important variable in waste management and its success should be supported by a high level of public awareness. The factors that can affect the behavior of society, including internal factors and external factors. The purpose of this research is to know the behavior of society in waste management, to know the relation of internal factor and external factor in waste management in East Denpasar Subdistrict.

The design of this study included cross sectional with stratified random sampling. The sample in this research is housewife who lives and settles and has (KTP) East Denpasar, as many as 100 respondents. The data collected in this research are the respondent's characteristic, respondent's behavior, internal and external factors and the factors driving the participation in waste management. The data is obtained then analyzed using SEM-PLS data analysis with the help of Smart PLS software.

Based on the results of SEM-PLS analysis show that from nine behavioral indicators in managing the waste studied found the result that the behavior of sorting organic and inorganic waste has the highest value to the behavior of the community in managing waste. The internal factor variables indicate that people's knowledge has the highest value in managing waste from the four indicators studied, while external factor variables show that law enforcement has the highest value of three meticulous indicators on the behavior of the community in managing waste in East Denpasar Subdistrict.

The conclusion of this research shows that there is a relationship between the behavior of managing waste with internal and external factors. Community behavior in sorting organic and inorganic waste in the category of good because it is supported by knowledge and awareness of good society in managing waste and by obeying the rules in disposing garbage.

Keywords: Community behavior, Waste management

\section{PENDAHULUAN}

Masalah sampah merupakan salah satu masalah lingkungan hidup yang sejak lama telah menjadi perhatian dunia dan perlu mendapat penanganan yang serius agar tidak menimbulkan dampak yang membahayakan. Semua orang tidak terlepas dari permasalahan sampah karena setiap orang menghasilkan sampah dari proses aktivitasnya. Meningkatnya volume sampah seiring dengan laju pertumbuhan penduduk, peningkatan teknologi, aktivitas sosial budaya dan pertumbuhan ekonomi masyarakat di suatu daerah (Azkha, 2007).

Kota Denpasar merupakan kota pusat pemerintahan di Propinsi Bali dan sebagai pusat kegiatan strategis yang menyebabkan banyak orang datang dan bermukim di Kota Denpasar. Berdasarkan data dari BPS (Badan pusat Statistik) tahun 2015, jumlah penduduk Kota Denpasar mencapai 880.600 jiwa. Banyaknya jumlah penduduk di Kota Denpasar berpengaruh pada volume sampah yang dihasilkan setiap hari. Produksi sampah di Kota Denpasar tahun 2016 rata-rata sebanyak 3.590,44 m3 perhari. Dari volume sampah tersebut $75 \%$ di antaranya adalah sampah organik dan sisanya $25 \%$ sampah anorganik (Sudarma, 2003).

Dari tahun ke tahun diperkirakan akan terjadi peningkatan volume sampah seiring dengan bertambahnya jumlah penduduk dan aktivitas konsumsi masyarakat. Setiap penduduk di Indonesia pada tahun 1995 menghasilkan sampah rata-rata $0,8 \mathrm{~kg}$ perkapita per hari. Di kota-kota besar seperti 
Jakarta dan Surabaya volume sampah yang dihasilkan, umumnya mengalami pertumbuhan masing-masing 6\% dan 5\%. Diperkirakan volume sampah perkotaan yang dihasilkan di Indonesia akan meningkat 5 kali lipat pada tahun 2020 (Sudarma, 2003).

Produksi sampah yang dihasilkan di Kota Denpasar khususnya di Kecamatan Denpasar Timur berbeda antara satu kecamatan dengan kecamatan lainnya tergantung jumlah penduduknya. Kota Denpasar memiliki empat kecamatan yaitu Denpasar Barat, Denpasar Timur, Denpasar Selatan, dan Denpasar Utara. Kecamatan Denpasar Timur merupakan satu dari empat kecamatan yang memiliki luas wilayah yang terkecil namun memiliki jumlah penduduk yang padat. Produksi sampah di Kecamatan Denpasar Timur tahun 2016 rata-rata sebanyak 615,16 m3 perhari. Pengelolaan sampah yang dilakukan masih menggunakan paradigma lama yaitu kumpul, angkut, buang yang dapat menyebabkan kinerja TPA semakin berat.

Dalam upaya pengelolaan sampah banyak hal yang telah dilakukan oleh DLHK Kota Denpasar, mulai dari penyediaan sarana prasarana TPS, sampai dengan pengangkutan ke tempat pengelolaan akhir, namun masih menyisakan sejumlah masalah. Salah satunya adalah kesadaran dan keterlibatan masyarakat dalam pengelolaan sampah belum maksimal, masih sebatas skala kecil di tingkat rumah tangga. Kebersihan masih sebatas di dalam rumah tangga yang bebas dari sampah, namun di luar rumah sampah belum dikelola dengan baik. Adanya lahan kosong, selokan, sungai dan tempat lainnya sering menjadi sasaran TPS liar.

Pengelolaan sampah permukiman memerlukan partisipasi aktif individu dan kelompok masyarakat agar peran pemerintah tidak semakin berat. Meningkatkan partisipasi masyarakat dalam pengelolaan sampah, dapat dilaksanakan dengan melibatkan masyarakat sebagai penghasil sampah terbesar, dengan membudayakan perilaku pengelolaan sampah semenjak dini dari rumah tangga, sebagai struktur terendah dalam pengelolaan sampah perkotaan (Nurdin, 2004).

Tanpa pengaruh stimulus yang di terima, perilaku manusia tidak muncul dengan sendirinya, baik stimulus yang bersifat eksternal maupun internal. Stimulus yang diterima sebagian besar perilaku manusia adalah akibat respon terhadap stimulus eksternal (Bimo,1999). Perilaku masyarakat merupakan variabel terpenting dalam pengelolaan sampah dan keberhasilannya harus di dukung oleh tingkat kesadaran masyarakat yang tinggi.

Perilaku masyarakat dalam mengelola sampah rumah tangga memberikan peran dalam menimbulkan emisi gas rumah kaca, seperti tindakan melakukan kegiatan membakar sampah dan membuang sampah sembarangan. Pelanggaran terhadap pembuangan sampah sembarangan tercatat
94 kasus dari bulan Januari sampai Juni 2017. Pemerintah telah melakukan tindakan tipiring terhadap pelanggaran tersebut dan sudah disidangkan. Kedepannya diharapkan penegakan hukum yang sudah ada tetap dipertahankan dan dijalankan secara konsisten oleh pemerintah untuk mengurangi permasalahan sampah.

Partisipasi masyarakat dalam pengelolaan sampah merupakan bentuk keterlibatan dan keikutsertaan masyarakat secara aktif dan sukarela dalam keseluruhan proses pengelolaan sampah. Perilaku sehat diharapkan dapat memelihara, meningkatkan kesehatan dan melindungi diri dari ancaman penyakit, sedangkan lingkungan sehat diharapkan dapat menciptakan lingkungan yang kondusif, bebas polusi, pemukiman yang sehat dan pengelolaan sampah yang sehat (Azkha, 2006).

Pengelolaan sampah menuju zero waste yang berbasis masyarakat perlu diterapkan secara komprehensif untuk meminimalkan terjadinya proses produksi sampah mulai dari sampah diproduksi sampai berakhirnya suatu proses produksi (Santoso, 2009). Konsep zero waste ini salah satunya dengan menerapkan paradigma baru dengan prinsip $3 \mathrm{R}$ yaitu reduce (mengurangi), reuse (menggunakan kembali) dan recycle (mendaur ulang) dengan menggunakan paradigma baru penanganan sampah yaitu kumpul, pilah, olah, angkut.

Paradigma baru sesuai Undang-Undang No 18 Tahun 2008, menilai sampah sebagai sumber daya bersifat ekonomis dan bermanfaat, sebagai kompos, energi, bahan bangunan maupun sebagai bahan baku industri, sedangkan yang dibuang adalah sampah yang benar-benar sudah tidak dapat dimanfaatkan dan tidak memiliki nilai ekonomis.

Berdasarkan hal tersebut menimbulkan ide untuk mengadakan penelitian di Kecamatan Denpasar Timur. Tujuan penelitian adalah (1) untuk mengetahui perilaku masyarakat di Kota Denpasar khususnya di Kecamatan Denpasar Timur dalam pengelolaan sampah, (2) mengetahui hubungan faktor internal yang meliputi pengetahuan, tingkat pendidikan, pendapatan dan waktu luang terhadap perilaku masyarakat dalam pengelolaan sampah, (3) mengetahui hubungan faktor eksternal yang meliputi sarana dan prasarana, sosialisasi dan penegakan hukum terhadap perilaku masyarakat dalam pengelolaan sampah.

\section{METODOLOGI}

\subsection{Lokasi dan Waktu Penelitian}

Lokasi yang dipilih dalam penelitian ini adalah di Kecamatan Denpasar Timur Kota Denpasar. Pemilihan lokasi penelitian dilakukan berdasarkan beberapa pertimbangan, salah satunya adalah Kecamatan Denpasar Timur merupakan kawasan padat penduduk dan penghasil sampah. Penelitian 
ini dilaksanakan pada bulan Pebruari sampai dengan bulan Mei 2017.

\subsection{Sumber Data}

Data yang digunakan dalam penelitian ini menggunakan data primer dan data sekunder. Data primer dalam penelitian ini berupa karakteristik responden, perilaku responden, faktor internal yang terdiri dari 4 (empat) indikator yaitu pengetahuan, tingkat pendidikan, pendapatan masyarakat dan waktu luang dan faktor eksternal yang terdiri dari 3 (tiga) indikator yaitu sarana dan prasarana, penegakkan hukum dan sosialisasi dalam pengelolaan sampah serta faktor pendorong partisipasi dalam pengelolaan sampah, dan di dukung hasil wawancara terstruktur langsung dari informan.

Data sekunder dalam penelitian meliputi gambaran geografi dan data kependudukan di Kecamatan Denpasar Timur, data dari instansi terkait Dinas Lingkungan Hidup dan Kebersihan (DLHK) Kota Denpasar, situs internet, gambaran geografi, literatur, jurnal-jurnal, skripsi, dan tesis serta laporan penelitian yang ada kaitannya dengan penelitian ini.

Penelitian ini menggunakan metode survai dengan desain cross sectional dimana data seluruh variabel penelitian dikumpulkan pada waktu yang sama. Populasi dalam penelitian ini adalah ibu rumah tangga yang tinggal dan menetap serta memiliki KTP di Kecamatan Denpasar Timur. Sedangkan jumlah sampelnya ditentukan dengan menggunakan perhitungan rumus Slovin sebanyak 100 responden. Penentuan sampel dalam penelitian ini adalah secara stratified random sampling. Jumlah masing-masing sampel tiap lokasi menggunakan proportionate sampling. Besaran sampel untuk setiap desa/kelurahan di Kecamatan Denpasar Timur ditentukan dengan menggunakan metode dari Taro Yamane.

\subsection{Instrumen Penelitian}

Instrumen penelitian yang digunakan dalam penelitian terdiri dari kuesioner; wawancara; observasi; dan dokumentasi;

\subsection{Prosedur Penelitian}

Prosedur penelitian yang dilakukan, yaitu:

1) Persiapan penelitian: menyiapkan enumerator, menyiapkan pembekalan materi isi dari kuesioner kepada enumerator, melakukan simulasi pelaksanaan penelitian dengan ujicoba kuesioner dengan sesama enumerator kemudian, melakukan ujicoba pengambilan data ke masyarakat, selanjutnya dilakukan evaluasi dari hasil pengambilan data, membahas kekurangan dalam pelaksanaan ujicoba, untuk kemudian enumerator siap mengambil data penelitian.

2) Pelaksanaan penelitian: melakukan pengambilan data responden dengan kuesioner dan melakukan wawancara;

3) Menentukkan variabel dan indikator yang berpengaruh yang diduga berperan terhadap perilaku masyarakat dalam pengelolaan sampah.

\subsection{Prosedur Analisis Data}

Proses analisis data dilakukan dengan tahapan sebagai berikut:

1) Metode analisis deskriptif

Melakukan pengumpulan data, penilaian data sekunder, interpretasi data, dan menarik kesimpulan atau generalisasi.

2) Metode analisis inferensia

Teknik analisis data yang digunakan adalah model persamaan struktural (Structural Equation Modeling - SEM) berbasis variance atau Component based SEM, yang terkenal disebut Partial Least Square (PLS). Estimasi parameter yang didapat dengan PLS dikategorika menjadi tiga yaitu weight estimate yang digunakan untuk menciptakan skor variabel laten, mencerminkan estimasi jalur (path estimate) yang menghubungkan variabel laten dan antar variabel laten dan blok indikatornya (loading), keterkaitan dengan means dan lokasi parameter (nilai konstan regresi) untuk indikator dan variabel laten. Berdasarkan kerangka konseptual penelitian yang dibangun atas dasar teori dan konsep, maka dapat digambarkan model empirik penelitian seperti Gambar 1.

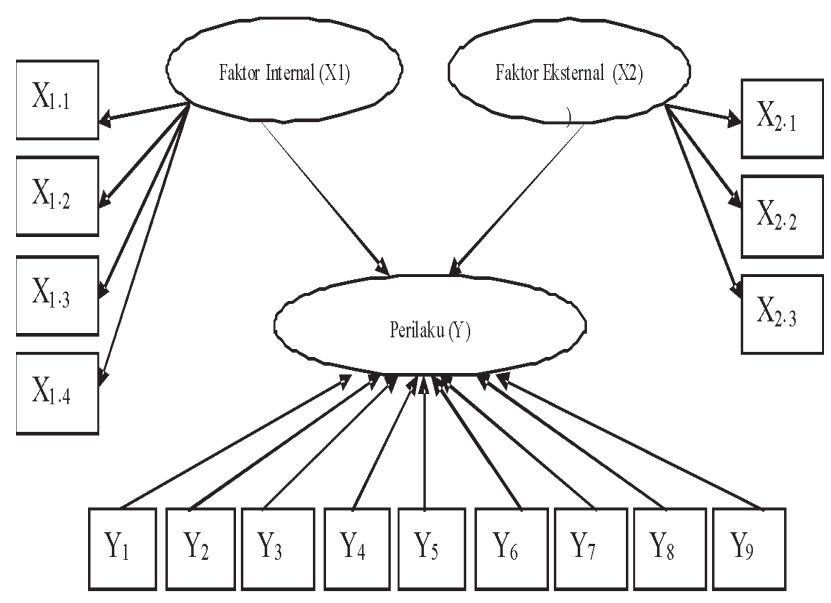

Gambar 1

Path diagram Hubungan Faktor Internal dan Faktor Eksternal terhadap Perilaku 


\section{HASIL DAN PEMBAHASAN}

\subsection{Perilaku Masyarakat dalam Pengelolaan Sampah di Kecamatan Denpasar Timur}

Dalam penelitian ini ingin diketahui adalah perilaku dalam mengelola sampah yang diduga dipengaruhi oleh variabel faktor internal dan variabel faktor eksternal. Variabel faktor internal dan faktor eksternal merupakan variabel bentukan (faktor sekunder) yang dibentuk dari sekumpulan indikator.

Deskripsi variabel perilaku dalam mengelola sampah terdiri atas 9 (sembilan) indikator. Nilai parameter masing-masing indikator pada variabel perilaku dalam mengelola sampah telah valid. Hal ini dapat dilihat dari nilai $t$-statistic (signifikansi) yang seluruhnya lebih besar dari cuts off sebesar 1,96. Nilai signifikansi masing-masing indikator dapat dilihat pada Tabel 1.

Berdasarkan Tabel 1 dibentuk persamaan model masing-masing indikator terhadap variabel laten perilaku dalam mengelola sampah sebagai berikut: $\mathrm{Y}_{1}=0,546 \mathrm{Y}+0,127 \mathrm{Y}_{2}=0,896 \mathrm{Y}+0,034 \mathrm{Y}_{3}=0,543 \mathrm{Y}$ $+0,072 \mathrm{Y}_{4}=0,777 \mathrm{Y}+0,047 \mathrm{Y}_{5}=0,545 \mathrm{Y}+0,076$ $\mathrm{Y}_{6}=0,539 \mathrm{Y}+0,113 \mathrm{Y}_{7}=0,539 \mathrm{Y}+0,082 \mathrm{Y}_{8}=0,548$ $\mathrm{Y}+0,125 \mathrm{Y}_{9}=0,527 \mathrm{Y}+0,114$

Persamaan tiap-tiap variabel pada indikator perilaku dalam mengelola sampah yang terdiri atas 9 (sembilan) indikator menunjukkan bahwa pernyataan memilah sampah organik dan anorganik $\left(\mathrm{Y}_{2}\right)$ memiliki kategori tertinggi yaitu sebesar 0,896, artinya indikator tersebut memiliki hubungan paling kuat terhadap perilaku responden dalam mengelola sampah rumah tangga. Indikator menghindari membakar sampah kering atau basah di lahan kosong $\left(\mathrm{Y}_{\mathrm{g}}\right)$ memiliki kategori terkecil yaitu sebesar 0,527 , artinya indikator tersebut memiliki peranan terendah terhadap perilaku responden dalam mengelola sampah rumah tangga .

Perilaku merupakan suatu cerminan sikap yang terlahir akibat interaksi antara manusia dengan lingkungan, sehingga perilaku individu dan masyarakat dapat mempengaruhi kondisi lingkungan dan kesadaran masyarakat mampu mempengaruhi hal tersebut. Berdasarkan hasil penelitian menunjukkan dari sembilan indikator capaian hasil perilaku dalam mengelola sampah menunjukkan bahwa pernyataan "memilah sampah organik dan anorganik" memiliki nilai yang paling tinggi artinya indikator tersebut memiliki hubungan paling dominan terhadap variabel perilaku dalam mengelola sampah.

Pemilahan sampah organik dan anorganik yang dilakukan di tingkat rumah tangga merupakan salah satu bentuk perilaku dan partisipasi masyarakat dalam menangani dan mengatasi masalah sampah di lingkungannya. Hal ini dapat dilihat dari kesadaran masyarakat dalam mengelola sampah rumah tangga secara rutin melakukan pemilahan sampah. Sampah yang dipilah masyarakat umumnya jenis sampah yang memiliki nilai ekonomis seperti botol/ gelas plastik, kaleng, dan kardus. Ini menunjukkan perilaku masyarakat dalam memilah sampah organik dan anorganik sudah baik. Masyarakat telah berpartisipasi aktif dengan menyediakan bak atau wadah sampah organik dan anorganik di lingkungan tempat tinggal mereka sebagai sarana utama dalam membuang sampah yang dihasilkan untuk menjaga kebersihan lingkungannya. Meskipun bukan wadah yang sempurna seperti tong sampah yang tertutup dan berisi tulisan warna warni, namun perilaku masyarakat dalam memilah sampah sudah baik sehingga dapat mengurangi kinerja TPA.

Tabel 1. Outer Loadings Konstruk Variabel Perilaku Dalam Mengelola Sampah

\begin{tabular}{|c|c|c|c|c|c|c|}
\hline & $\begin{array}{c}\text { Original } \\
\text { Sample (0) }\end{array}$ & $\begin{array}{l}\text { Sample } \\
\text { Mean (M) } \\
\text { (STDEV) }\end{array}$ & $\begin{array}{l}\text { Standard } \\
\text { Deviation } \\
\text { (STERR) }\end{array}$ & $\begin{array}{l}\text { Standard } \\
\text { Error }\end{array}$ & $\begin{array}{l}\text { TS Statistics } \\
(|\mathrm{O} / \mathrm{STERR}|)\end{array}$ & Keterangan \\
\hline$Y_{1} \cdot !$ Membuang sampah pada tempat sampah & 0.546222 & 0.443026 & 0.127092 & 0.127092 & 3.636928 & Signifikan \\
\hline$Y_{2} \cdot !$ Memilah sampah organik dan anorganik & 0.896222 & 0.882349 & 0.034206 & 0.034206 & 26.200346 & Signifikan \\
\hline $\begin{array}{l}Y_{3} \cdot ! \text { Melakukan pengolahan sampah organik } \\
\text { sepertidaun-daunan, sisa makanan menjadi } \\
\text { kompos di masing-masing rumah tangga }\end{array}$ & 0.543360 & 0.428927 & 0.072394 & 0.072394 & 5.989528 & Signifikan \\
\hline $\begin{array}{l}Y_{4} ! \text { ! Menggunakan kembali barang-barang yang tidak } \\
\text { terpakai lagi, seperti kaleng bekas untuk pot bunga } \\
\text { atau tempat menyimpan bumbu masak, dan lain-lain }\end{array}$ & 0.777770 & 0.765048 & 0.046628 & 0.046628 & 16.680296 & Signifikan \\
\hline $\begin{array}{l}Y_{5} \cdot ! \text { Menggunakan produk yang dapat diisi ulang refill) } \\
\text { seperti minyak goreng atau tisu refill. }\end{array}$ & 0.544984 & 0.436053 & 0.075548 & 0.075548 & 5.954427 & Signifikan \\
\hline $\begin{array}{l}Y_{6} ! \text { ! Membawa keranjang/tempat menaruh barang dari rumah } \\
\text { untuk mengurangi penggunaan barang yang dapat } \\
\text { menghasilkan sampah saat berbelanja }\end{array}$ & 0.538629 & 0.372466 & 0.112523 & 0.112523 & 3.433002 & Signifikan \\
\hline$Y_{7} !$ Menegur orang lain bila membuang sampah sembarangan & 0.539685 & 0.394340 & 0.081895 & 0.081895 & 4.845917 & Signifikan \\
\hline$Y_{8} \cdot !$ Menghindari menimbun sampah di dalam rumah & 0.548037 & 0.464038 & 0.125080 & 0.125080 & 3.840537 & Signifikan \\
\hline $\begin{array}{l}Y_{9}^{\circ} ! \text { Menghindari membakar sampah } \\
\text { kering atau basah di lahan kosong }\end{array}$ & 0.526624 & 0.248093 & 0.113760 & 0.113760 & 2.340416 & Signifikan \\
\hline
\end{tabular}


Sesuai dengan hasil penelitian Wardani (2004), sikap atas masalah sampah memberikan pengaruh terhadap partisipasi masyarakat dalam pengelolaan sampah dengan nilai asosiasi 0,428. Respon yang timbul dari masyarakat untuk berpartisipasi dalam bentuk swadaya dipengaruhi oleh sikap, persepsi dan pengalamannya. Menurut Tamond (2008), sikap merupakan evaluasi terhadap suatu obyek, tentang suka atau tidak suka, tertarik atau tidak tertarik sedangkan faktor penentu partisipasi masyarakat dalam pengelolaan sampah adalah kesadaran masyarakat (Fatin, 2011).

Penelitian lebih lanjut menunjukkan hasil, bahwa responden yang mengelola sampah dengan prinsip swakelola sampah sebesar 51\%, membuang ke TPS resmi (ada kontainer) sebanyak 24\%, sedangkan $15 \%$ masih diambil oleh truk sampah dari DLHK. Sisanya 10\% responden masih melakukan pengelolaan sampah dengan melakukan tindakan membakar sampah di lahan kosong.

Sesuai dengan wawancara yang dilakukan terhadap lembaga lokal, sistem manajemen pengelolaan sampah kepada masyarakat dilakukan dengan pendekatan block leaders yang menekankan pada sistem pengumpulan sampah yang terpilah. Masyarakat diarahkan untuk melakukan pemilahan sampah organik dan anorganik. Hubungan yang sinergi antara lembaga dinas dan adat yang terdapat di suatu desa memudahkan dalam upaya penggerakkan masyarakat. Peran pemimpin lembaga, pemimpin lokal atau pemimpin agama memberikan pengaruh yang sangat besar terhadap partisipasi masyarakat. Tokoh masyarakat dan lembaga lokal selau berusaha untuk menjadikan lingkungan bersih dengan menghindari adanya TPS liar. Beberapa kontainer-kontainer sampah sudah dikurangi agar masyarakat melakukan swakelola sampah sehingga pengelolaan sampah dapat dilakukan secara mandiri oleh masyarakat.

Menurut Green (1991), menyatakan bahwa tokoh masyarakat merupakan tokoh sentral yang menjadi acuan masyarakat dalam berperilaku. Adanya dukungan yang positif dari tokoh masyarakat merupakan salah satu faktor pendorong terjadinya perubahan perilaku (Notoatmodjo, 2007). Tokoh masyarakat dan lembaga lokal yang ada di masyarakat adalah merupakan institusi terdekat yang memahami kondisi dan karakteristik masyarakatnya. Menurut hasil penelitian Tandipanga (2008), di RW 11 Cibangkong menyatakan bahwa lembaga lokal sangat berpengaruh terhadap efektifitas pengelolaan sampah. Permasalahan sampah tidak dapat diselesaikan sendiri oleh pemerintah tanpa partisipasi dari seluruh sektor yang ada.

Perilaku masyarakat di Kecamatan Denpasar Timur dalam mengelola sampah rumah tangga sudah dalam kategori baik, yang ditunjukkan melalui kesediaan masyarakat dengan melakukan pewadahan sampah secara mandiri. Masyarakat telah melakukan pemilahan sampah organik dan anorganik, telah menerapkan prinsip $3 \mathrm{R}$ yaitu reduce (mengurangi), reuse (menggunakan kembali), recycle (mendaur ulang), dan tidak membuang sampah sembarangan serta menghindari kegiatan membakar sampah.

\subsection{Hubungan Faktor Internal yang meliputi Pengetahuan, Tingkat Pendidikan, Penda- patan dan Waktu Luang Terhadap Perilaku Masyarakat dalam Pengelolaan Sampah \\ Deskripsi variabel faktor internal terdiri atas} empat indikator yaitu pengetahuan, tingkat pendidikan, pendapatan, dan waktu luang.

Nilai parameter masing-masing indikator pada variabel faktor internal telah valid. Hal ini dapat dilihat dari nilai $t$-statistic (signifikansi) yang seluruhnya lebih besar dari cuts off sebesar 1,96. Nilai signifikansi masing-masing indikator dapat dilihat pada Tabel 2.

Berdasarkan tabel 2 dibentuk persamaan model masing-masing indikator terhadap variabel laten faktor internal sebagai berikut:

$$
\begin{aligned}
& \mathrm{X}_{1.1}=0,738 \mathrm{X}_{1}+0,115 \\
& \mathrm{X}_{1.2}=0,538 \mathrm{X}_{1}+0,138 \\
& \mathrm{X}_{1.3}=0,598 \mathrm{X}_{1}+0,112 \\
& \mathrm{X}_{1.4}=0,573 \mathrm{X}_{1}+0,117
\end{aligned}
$$

Persamaan tiap-tiap indikator pada variabel faktor internal yang terdiri atas empat indikator yaitu pengetahuan, tingkat pendidikan, pendapatan, dan waktu luang, menunjukkan bahwa indikator pengetahuan masyarakat $\left(\mathrm{X}_{1.1}\right)$ memiliki kategori yang paling tinggi yaitu sebesar 0,738 , artinya indikator tersebut memiliki hubungan paling

\begin{tabular}{|c|c|c|c|c|c|c|}
\hline & $\begin{array}{c}\text { Original } \\
\text { Sample(0) }\end{array}$ & $\begin{array}{c}\text { Sample } \\
\text { Mean (M) }\end{array}$ & $\begin{array}{l}\text { Standard } \\
\text { Deviation } \\
\text { (STDEV) }\end{array}$ & $\begin{array}{c}\text { Standard } \\
\text { Error (STERR) }\end{array}$ & $\begin{array}{c}\text { TStatistics } \\
(\mid \text { O/STERR|) }\end{array}$ & Keterangan \\
\hline Pengetahuan $(X 1.1)<-$ INTERNAL & 0.738706 & 0.707710 & 0.115552 & 0.115552 & 6.392840 & Signifikan \\
\hline Pendidikan $(\mathrm{X} 1.2)<-$ INTERNAL & 0.537835 & 0.508217 & 0.138378 & 0.138378 & 3.886704 & Signifikan \\
\hline Pendapatan $(\mathrm{X} 1.3)<-$ INTERNAL & 0.597526 & 0.588130 & 0.112261 & 0.112261 & 5.322669 & Signifikan \\
\hline Waktu Luang $(X 1.4)<-$ INTERNAL & 0.572915 & 0.576348 & 0.117777 & 0.117777 & 4.864390 & Signifikan \\
\hline
\end{tabular}
dominan terhadap variabel faktor internal. Indikator pendidikan $\left(\mathrm{X}_{1.2}\right)$ memiliki kategori paling kecil yaitu

Tabel 2. Outer loadings konstruk variabel faktor internal 
sebesar 0,537 , artinya indikator tersebut memiliki hubungan paling rendah terhadap variabel faktor internal. Berdasarkan hasil penelitian tiap-tiap indikator pada variabel faktor internal menunjukkan bahwa indikator pengetahuan masyarakat memiliki kategori tertinggi , artinya indikator tersebut berperan besar terhadap variabel faktor internal. Indikator pendidikan formal memiliki kategori terendah dalam pengelolaan sampah.

Pengetahuan dan sikap seseorang akan berperan dalam tindakan yang dilakukannya. Pengetahuan merupakan suatu tahap awal seseorang mulai mengenal ide baru dan memahami ide tersebut. Hasil wawancara terhadap responden diketahui bahwa pengetahuan masyarakat sudah baik dalam pengelolaan sampah, pengetahuan masyarakat dalam melakukan pengelolaan sampah yang dilakukan secara rutin jauh lebih baik dengan masyarakat yang tidak pernah melakukan pengelolaan sampah, meskipun tingkat pendidikan formalnya lebih tinggi. Ini menunjukkan pengetahuan yang dimiliki masyarakat dalam mengelola sampah sudah baik.

Pengetahuan masyarakat diperoleh dari berbagai sumber seperti melalui dunia pendidikan formal maupun dari media ataupun melalui penyuluhan dan interaksi sesama anggota masyarakat. Pengetahuan dan pendidikan dapat mengubah sikap dan pola pikir seseorang dalam bertindak. Tindakan seseorang lebih mudah salah tanpa pengetahuan dibandingkan bila seseorang melakukan tindakan yang didasarkan oleh pengetahuan. Ilmu pengetahuan dapat meminimalkan kesalahan dalam praktek dan tindakan. Perilaku dalam bertindak yang didasarkan kepada ilmu pengetahuan lebih bertahan lama dan menjadi kebiasaan karena mengetahui risiko tindakan yang dilakukan. Semakin baik pengetahuan semakin baik pula perilaku mengelola lingkungan.

Menurut hasil penelitian yang dilakukan Dewi (2010), menyebutkan pengetahuan memberi pengaruh terhadap partisipasi masyarakat dan terbukti bahwa sebanyak $27,78 \%$ responden yang tidak memiliki pengetahuan tentang cara pengelolaan sampah tidak melakukan pengelolaan sampah.

Gardner \& Stern (1996) menyatakan bahwa penyebab perubahan perilaku seseorang menjadi ramah lingkungan adalah informasi khusus ke bidang yang diinginkan. Mendidik masyarakat merupakan hal terpenting dan bukan melihat dari tingkat pendidikan masyarakat. Masyarakat membutuhkan informasi bukan hanya informasi yang bersifat menyampaikan tentang pengelolaan sampah yang baik tetapi menekankan pada informasi yang dapat mendorong masyarakat untuk mengubah perilaku.

Gardner (1996), menyatakan, perubahan perilaku sangat lemah hanya dengan sekedar memberikan informasi. Memberikan informasi harus berupa feedback yang dikaitkan dengan perilaku yang dilakukan oleh masyarakat. Seseorang berperilaku atau melakukan tindakan disebabkan karena pengetahuan, kepercayaan dan sikap yang dimilikinya (Soekidjo Notoatmodjo, 2003). Chan, (1998) menyatakan bahwa tingkat pendidikan tidak berpengaruh pada partisipasi pengelolaan sampah domestik di Hongkong.

Tingkat pengetahuan masyarakat merupakan kategori tertinggi pada variabel faktor internal yang paling menentukan perilaku masyarakat dalam mengelola sampah, indikator lainnya adalah pendapatan masyarakat dan waktu luang yang dimiliki masyarakat, sedangkan tingkat pendidikan merupakan kategori terkecil dalam menentukan perilaku masyarakat dalam mengelola sampah rumah tangga.

\subsection{Hubungan Faktor Eksternal yang meliputi Faktor-Faktor Sarana dan Prasarana Persampahan, Sosialisasi dan Penegakan Hukum Terhadap Perilaku Masyarakat Dalam Pengelolaan Sampah}

Deskripsi variabel faktor eksternal terdiri atas tiga indikator yaitu sarana dan prasarana, penegakan hukum, dan sosialisasi.

Nilai parameter masing-masing indikator pada variabel faktor eksternal telah valid. Hal ini dapat dilihat dari nilai $t$-statistic (signifikansi) yang seluruhnya lebih besar dari cuts off sebesar 1,96. Nilai signifikansi masing-masing indikator dapat dilihat pada Tabel 3.

Berdasarkan tabel 3 tersebut dibentuk persamaan model masing-masing indikator terhadap variabel laten faktor eksternal sebagai berikut:

$$
\begin{aligned}
& \mathrm{X}_{2.1}=0,501 \mathrm{X} 2+0,128 \\
& \mathrm{X}_{2.2}=0,962 \mathrm{X} 2+0,110 \\
& \mathrm{X}_{2.3}=0,536 \mathrm{X} 2+0,129
\end{aligned}
$$

\begin{tabular}{|c|c|c|c|c|c|c|}
\hline & $\begin{array}{c}\text { Original } \\
\text { Sample(0) }\end{array}$ & $\begin{array}{c}\text { Sample } \\
\text { Mean (M) }\end{array}$ & $\begin{array}{l}\text { Standard } \\
\text { Deviation } \\
\text { (STDEV) }\end{array}$ & $\begin{array}{c}\text { Standard } \\
\text { Error (STERR) }\end{array}$ & $\begin{array}{c}\text { TStatistics } \\
\text { (|O/STERR|) }\end{array}$ & Keterangan \\
\hline Sarana dan Prasarana $\left(\mathrm{X}_{2.1}\right) \cdot$ !EKSTERNAL & 0.501791 & 0.488942 & 0.128219 & 0.128219 & 3.913558 & Signifikan \\
\hline Penegakkan hukum $\left(X_{2.2}^{2 .}\right) \cdot$ !EKSTERNAL & 0.962580 & 0.946166 & 0.110945 & 0.110945 & 8.676182 & Signifikan \\
\hline Sosialisasi $\quad\left(\mathrm{X}_{2.3}\right) \cdot$ !EKSTERNAL & 0.536011 & 0.526519 & 0.129058 & 0.129058 & 4.153243 & Signifikan \\
\hline
\end{tabular}

Tabel 3. Outer Loadings Konstruk Variabel Faktor Eksternal 
Persamaan tiap-tiap indikator pada variabel faktor eksternal yang terdiri atas tiga indikator yaitu sarana dan prasarana, penegakan hukum, dan sosialisasi menunjukkan bahwa indikator penegakan hukum $\left(\mathrm{X}_{2,}\right)$ memiliki kategori paling tinggi yaitu sebesar 0,962 , artinya indikator tersebut memiliki hubungan paling besar terhadap variabel faktor eksternal. Indikator sosialisasi $\left(\mathrm{X}_{2.3}\right)$ memiliki kategori paling kecil yaitu sebesar 0,536 , artinya indikator tersebut memiliki hubungan paling rendah terhadap variabel faktor eksternal.

Menurut Bimo (1999), perilaku manusia tidak muncul dengan sendirinya tanpa adanya stimulus yang di terima, baik itu stimulus bersifat eksternal maupun internal. Sebagian besar perilaku manusia akibat respon terhadap stimulus eksternal yang diterima.

Berdasarkan hasil penelitian faktor eksternal menunjukkan bahwa indikator penegakan hukum memiliki kategori tertinggi, artinya indikator tersebut memiliki hubungan terbesar terhadap variabel faktor eksternal, sedangkan sosialisasi memiliki kategori terendah terhadap perilaku dalam mengelola sampah.

Penegakkan hukum dalam penelitian ini memiliki pengertian pemberian sangsi pada masyarakat yang membuang sampah sembarangan. Hasil penelitian diketahui bahwa kesadaran responden terhadap lingkungan di Kecamatan Denpasar Timur menunjukkan pemahaman dan perilaku masyarakat yang baik.

Peraturan penegakkan hukum umumnya memiliki peranan penting dalam membentuk perilaku masyarakat. Peraturan yang diikuti dengan penegakkan hukum yang tepat dapat mendorong masyarakat untuk mematuhi peraturan tersebut. Menurut Fatin (2011), faktor terpenting pada partisipasi masyarakat adalah kesadaran masyarakat dalam pengelolaan sampah.

Kesadaran masyarakat tentang pengelolaan sampah di Kecamatan Denpasar Timur dalam kondisi baik. Masyarakat dengan kesadarannya berpartisipasi aktif dalam pengelolaan sampah di lingkungannya masing-masing Penegakkan hukum merupakan kategori tertinggi pada variabel faktor eksternal yang paling berperan dalam meningkatkan kesadaran perilaku masyarakat dalam mengelola sampah. Faktor lainnya adalah penyediaan sarana dan prasarana, sedangkan sosialisasi dalam pengelolaan sampah merupakan kategori yang terendah dalam mengelola sampah. Hal ini disebabkan karena masyarakat sudah memperoleh informasi terkait materi sosialisasi yang disampaikan, sehingga menjadi faktor yang terkecil berkontibusi terhadap perilaku masyarakat.

Upaya penegakkan hukum di Kota Denpasar sudah menjadi agenda tetap yang terus dilakukan untuk mengurangi sampah, namun pelanggaran masih terus terjadi. Peraturan Walikota Denpasar
Nomor 3 Tahun 2012 Tentang Penetapan Jadwal Waktu Pembuangan Sampah Serta Ketentuan Dan Tata Cara Pemotongan Pohon Perindang Di Kota Denpasar, perlu lebih disosialisasikan. Diharapkan dengan adanya penegakkan hukum yang berjalan secara konsisten masyarakat memiliki efek jera terhadap pelanggaran yang dilakukan sehingga dapat menjadikan lingkungan bersih dari sampah.

Untuk lebih jelasnya hubungan faktor internal dan faktor eksternal ke perilaku dapat dilihat pada diagram.

\section{SIMPULAN DAN SARAN}

\subsection{Simpulan}

Berdasarkan hasil penelitian dan pembahasan dapat ditarik beberapa simpulan sebagai berikut: 1 . Perilaku masyarakat di Kecamatan Denpasar Timur dalam mengelola sampah rumah tangga sudah dalam kategori baik, yang ditunjukkan melalui kesediaan masyarakat dengan melakukan pewadahan sampah secara mandiri. Masyarakat telah melakukan pemilahan sampah organik dan anorganik, telah menerapkan prinsip $3 \mathrm{R}$ yaitu reduce (mengurangi), reuse (menggunakan kembali), recycle (mendaur ulang), dan tidak membuang sampah sembarangan serta menghindari kegiatan membakar sampah. 2 . Tingkat pengetahuan masyarakat merupakan kategori tertinggi pada variabel faktor internal yang paling menentukan perilaku masyarakat dalam mengelola sampah, indikator lainnya adalah pendapatan masyarakat dan waktu luang yang dimiliki masyarakat, sedangkan tingkat pendidikan merupakan kategori terkecil dalam menentukan perilaku masyarakat dalam mengelola sampah rumah tangga. 3. Penegakkan hukum merupakan kategori tertinggi pada variabel faktor eksternal yang paling berperan dalam meningkatkan kesadaran perilaku masyarakat dalam mengelola sampah. Faktor lainnya adalah penyediaan sarana dan prasarana, sedangkan sosialisasi dalam pengelolaan sampah merupakan kategori terkecil dalam mengelola sampah. Hal ini disebabkan karena masyarakat sudah memperoleh informasi terkait materi sosialisasi yang disampaikan, sehingga menjadi faktor yang terkecil berkontibusi terhadap perilaku masyarakat.

\subsection{Saran}

Berdasarkan simpulan di atas dapat disarankan beberapa hal sebagai berikut.

1. Kepada Pemerintah: a). Melakukan sosialisasi pelayanan dan pengangkutan sampah organik dan anorganik ke masyarakat dan apabila masyarakat tidak melakukannya maka sampah tidak akan terlayani dalam pengangkutan, baik yang diangkut oleh pemerintah lewat DLHK, maupun secara swakelola. b). Perlu adanya 
perbedaan jenis sampah dan waktu pengangkutan sampah, antara sampah organik dan anorganik. c). Perlu adanya penyediaan lahan kosong untuk melakukan komposting baik itu lahan milik sendiri ataupun sewa, hal ini sangat mungkin dilakukan dengan memanfaatkan dana desa yang diberikan oleh pemerintah pusat. d). Mengalokasikan bantuan dana desa yang diberikan secara rutin kepada setiap desa, untuk memberikan perhatian pada masalah penanganan sampah secara mandiri. e). Penyediaan TPS atau depo sampah yang memenuhi syarat sehingga tidak mencemari lingkungan.

2. Kepada Masyarakat: a). Partisipasi masyarakat yang sudah baik agar tetap ditingkatkan dan mengajak seluruh anggota keluarga tetap menjaga kebersihan lingkungan dan menerapkan prinsip 3R dalam mengelola sampah rumah tangga. b). Perilaku masyarakat dalam melakukan pemilahan sampah sudah berkategori baik, namun diharapkan masyarakat mengurangi penggunaan barangbarang yang akan menghasilkan sampah plastik.

\section{DAFTAR PUSTAKA}

Azkha. N. 2006. “Analisis Timbulan, Komposisi Dan Karakteristik Sampah di Kota Padang”. Jurnal Kesehatan Masyarakat, September 2006, I (1).

Azkha. N. 2007. "Pemanfaatan Komposter Berskala Rumah Tangga”. Jurnal Kesehatan Masyarakat. September. I (2).

Chan, K. 1998. "Mass Communication and ProEnvironment Behaviour : Waste Recycling in Hong Kong”. Journal of Environment, 52 : 317 -325 .

Dewi. A.S dan Warmadewanthi. 2010. Kajian Model Pengelolaan Sampah Berbasis Masyarakat Di Kecamatan Wonocolo Kota Surabaya. Prosiding Seminar Nasional Manajemen Teknologi IX. Surabaya : Program Studi MMT-ITS.
Fatin, S. et all. 2011. A Review On The Succes Factors For Community Participation In Solid Waste Management. Pånàng. Màlàysià : Procååding of Intårnàtionàl Confåråncå On Mànàgåmånt (ICM 2011).

Gardner, G. T. and P.C. Stern, 1996, Environmental Problems and Human Behaviour. A Simon \& Schuster Company. Massachusets.

Green, Lawrence W. 1991. Health Promotion Planning An Educational and Anvironmental Approach. Mayfield Publishing Company. Mountain View.

Nurdin Usman, 2004, Implementasi dalam Birokrasi Pembangunan, Bandung

Notoatmodjo, S. 2003. Pendidikan dan Perilaku Kesehatan. Jakarta : PT Rineka Cipta.

Notoatmodjo, S. 2007. Promosi Kesehatan dan Ilmu Perilaku. Jakarta : PT Rineka Cipta.

Sudarma, I M. 2003. Integrated Solid Waste Management. Naskah Lengkap Short Course on Environmental Polution Control and Management. Denpasar 25 Agustus - 19 September.

Tamond, Z. E. 2008. Partisipasi Masyarakat Dan Teknik Pengelolaan Sampah Di Pemukiman. Jurnal Formas. Vol.1 (4) Juni : 277-283.

Tandipanga, F.B. 2008. "Faktor-Faktor Yang Mempengaruhi Peran Masyarakat Terhadap Efektifitas Pengelolaan Sampah”. Jurnal Komunitas. Vol. 4 (1) April.

Undang-undang No. 18 Tahun 2008 dan Permen PU No. 21/PRT/M/2006.

Wardani, C. 2004. "Partispasi Masyarakat Pada Kegiatan Pemilahan Sampah Rumah Tangga" (Tesis). Jakarta : Program Studi Ilmu Lingkungan Pascasarjana Universitas Indonesia.

Walgito, Bimo. 1999. Psikologi Sosial (Suatu Pengantar). Andi, Yogyakarta. 